\title{
Pengembangan Metode Diskusi Bermuatan Presentasi Sistem Rotasi pada Mata Kuliah Trigonometri
}

\author{
Ferdinandus Ardian $\mathrm{Ali}^{1 *}$, Emilianus Jehadus ${ }^{2}$, Sebastianus Fedi $^{3}$ \\ ${ }^{1,2,3}$ Universitas Katolik Santu Paulus Ruteng \\ *ardi0807068703@gmail.com
}

Diterima: Mei 2019. Disetujui: Juni 2019. Dipublikasikan: Juli 2019.

\begin{abstract}
ABSTRAK
Penelitian ini merupakan penelitian pengembangan dalam bidang pembelajaran, yakni pengembangan metode diskusi menjadi metode diskusi yang bermuatan presentasi sistem rotasi. Langkah-langkah pengembangan pada penelitian ini dilakukan dengan memodifikasi model pengembangan 4D yaitu tahap pendefinisian (define), tahap perancangan (design), tahap pengembangan (develop), dan tahap penyebaran (disseminate). Penelitian ini bertujuan untuk menghasilkan metode diskusi bermuatan presentasi sistem rotasi yang layak (valid, praktis, dan efektif) digunakan dalam pembelajaran mata kuliah trigonometri. Uji coba penggunaan metode diskusi bermuatan presentasi sistem rotasi ini dilakukan kepada mahasiswa Program Studi Pendidikan Matematika FKIP Universitas Katolik Santu Paulus Ruteng angkatan tahun 2018. Instrumen pengumpulan data yang digunakan adalah tes, angket, dan wawancara. Tes digunakan untuk mengetahui tingkat efektifitas dari metode diskusi bermuatan presentasi sistem rotasi yang diberikan kepada mahasiswa. Angket digunakan untuk mengetahui tingkat kevalidan dan tingkat kepraktisan dari metode diskusi bermuatan presentasi sistem rotasi. Angket kevalidan diberikan kepada 2 orang ahli pada bidang pendidikan matematika, sedangkan angket kepraktisan diberikan kepada mahasiswa setelah mereka mengikuti perkuliahan trigonometri yang menggunakan metode diskusi bermuatan presentasi sistem rotasi. Wawancara dilakukan untuk mendapatkan infromasi langsung terkait masalah yang dihadapi atau dialami oleh mahasiswa selama mengikuti perkuliahan trigonometri sebelum menggunakan metode diskusi bermuatan presentasi sistem rotasi. Berdasarkan hasil analisis data diperoleh kesimpulan bahwa metode diskusi bermuatan presentasi sistem rotasi yang telah dikembangkan ini dinyatakan layak (valid, praktis, dan efektif). Dengan menerapakan metode diskusi bermuatan presentasi sistem rotasi pada pembelajaran mata kuliah trigonometri, seluruh mahasiswa aktif selama proses pembelajaran melalui keterlibatan setiap mahasiswa pada tahap presentasi karena mekanisme presentasi menggunakan sistem rotasi. Oleh karena itu, maka metode diskusi bermuatan presentasi sistem rotasi ini dapat digunakan secara luas kepada kelas-kelas lain pada pembelajaran mata kuliah trigonometri.
\end{abstract}

Kata kunci: metode diskusi, presentasi, sistem rotasi, trigonometri.

\section{ABSTRACT}

This research is a development research in the field of learning, namely the development of discussion methods into a discussion method that contains rotation system presentations. The development steps in this study were done by modifying the $4 D$ development model, namely defining, designing, developing and disseminate. This study aims to produce a discussion method that contains a proper (valid, practical, and effective) rotation system presentation used in trigonometry learning. The trial using the discussion method with the presentation of the rotation system was carried out to students of the Mathematics Education Study Program FKIP Santu Paulus Ruteng Catholic University in 2018. The instruments of data collection used were tests, questionnaires, and interviews. The test is used to determine the level of effectiveness of the discussion method with a rotation system presentation given to students. Questionnaire is used to determine the level of validity and practicality of the discussion method with a rotation system presentation. The validity questionnaire was given to 2 experts in the field of mathematics education, while the practicality questionnaire was given to students after they took the trigonometry lecture using a discussion method with a rotation system presentation. Interviews were conducted to obtain direct information regarding problems faced or experienced by students during their trigonometry lectures before using the discussion method with a rotation system presentation. Based on the results of data analysis, it was concluded that the discussion method with the presentation of the rotation system that had been developed was declared feasible (valid, practical, and effective). By applying the discussion method with the presentation of the rotation system to trigonometric course learning, all students are active during the learning process through the involvement of each student at the presentation stage because the presentation mechanism uses a rotation system. Therefore, the method of discussion containing rotation system presentations can be used widely to other classes in trigonometry learning.

Keywords: method of discussion, presentation, rotation system, trigonometry.

How to Cite: Ali, F. A., Jehadus, E., \& Fedi, S. (2019). Pengembangan Metode Diskusi Bermuatan Presentasi Sistem Rotasi pada Mata Kuliah Trigonometri. Journal Of Medives : Journal Of Mathematics Education IKIP Veteran Semarang, 3(2), 331-343. 


\section{PENDAHULUAN}

\section{Latar Belakang}

Proses pembelajaran matematika yang dilakukan di dalam ruangan kuliah diarahkan untuk memberikan pemahaman materi yang baik kepada mahasiswa. Proses mentransfer ilmu yang dilakukan oleh dosen kepada mahasiswa dalam suatu proses pembelajaran dapat dilakukan dengan menggunakan model pembelajaran, pendekataan pembelajaran, metode pembelajaran, strategi pembelajaran, atau teknik pembelajaran. Oleh karena itu, dosen dapat memilih salah satu atau gabungan dari beberapa cara tersebut sehingga tujuan pembelajaran dapat tercapai secara maksimal.

Pemilihan cara tersebut tentunya harus disesuaikan dengan karakteristik dan kondisi dari mahasiswa yang diajarkan. Pada proses pembelajaran, penggunaan suatu metode pembelajaran dapat mempermudah mahasiswa untuk menguasai materi dengan baik. Menurut (Lutvaidah, 2015) bahwa metode pembelajaran merupakan cara yang digunakan oleh guru dalam menjalankan fungsinya dan merupakan alat untuk mencapai tujuan pembelajar-an.

Salah satu metode yang sering diterapkan pada proses pembelajaran matematika adalah metode diskusi. Menurut Suryosubroto (2009), bahwa metode diskusi adalah suatu cara penyajian bahan pelajaran dimana guru memberi kesempatan kepada para siswa (kelompok-kelompok siswa) untuk mengadakan perbincangan ilmiah guna mengumpulkan pendapat, membuat kesimpulan atau penyusunan berbagai alternatif pemecahan atas sesuatu masalah. Selanjutnya Majid (2013) menjelaskan bahwa diskusi adalah metode pembelajaran yang menghadapkan siswa pada suatu permasalahan.

Dalam proses pembelajaran, metode diskusi tidak hanya dapat diterapkan kepada siswa tetapi juga dapat diterapkan kepada mahasiswa. Hal ini dikarenakan bahwa siswa dan mahasiswa sama-sama sebagai orang yang menjadi sasaran dari tujuan dilakukannya suatu proses pembelajaran.

Melalui metode diskusi, mahasiswa dituntut untuk membahas masalah atau materi secara bersama-sama dalam satu kelompok diskusi, kemudian dipresentasikan kepada kelompok lain di depan kelas. Dalam penerapan metode diskusi, mahasiswa dituntut untuk aktif berdiskusi dalam kelompok sehingga dapat memecahkan masalah atau menguasai materi yang sedang didiskusikan dalam kelompok. Melalui penggunaan metode diskusi, mahasiswa dilatih untuk mengasah kemampuan komunikasi mereka tentang cara mentrasnfer ilmu kepada orang lain, dimana kemampuan tersebut akan menjadi modal pengetahuan ketika mereka nantinya telah lulus kuliah kemudian menjadi guru.

Mahasiswa calon guru dituntut untuk cakap dalam penguasaan materi maupun cakap dalam berkomunikasi, termasuk bagi setiap mahasiswa calon guru dibidang pendidikan matematika. Trigonometri merupakan salah satu cabang ilmu matematika yang di dalamnya mengandung konsep-konsep abstrak yang dapat digunakan untuk memecahkan berbagai masalah dalam kehidupan manusia. Hal tersebut 
menjadi alasan utama sehingga trigonometri dijadikan sebagai salah satu mata kuliah keilmuan yang wajib dipelajari oleh setiap mahasiswa pada program studi pendidikan matematika. Menguasai materi trigonometri dengan baik akan menjadi modal besar bagi mahasiwa sehingga dapat menerapkan ilmu tersebut ketika nantinya mereka menjadi guru di bidang pendidikan matematika.

Berdasarkan hasil observasi awal yang dilakukan oleh peneliti pada pertemuan pertama dan kedua ketika mengajar Mata Kuliah Trigonometri kepada mahasiswa Prodi Pendidikan Matematika FKIP Universitas Katolik Indonesia Santu Paulus Ruteng angkatan tahun 2018 ditemukan bahwa tidak semua mahasiswa berpartisipasi aktif ketika melakukan diskusi kelompok. Selain itu, ketika peneliti melakukan wawancara tidak terstruktur di luar kelas dengan mahasiswa ditemukan bahwa mereka akan terlibat aktif dalam diskusi hanya jika diperintahkan oleh dosen, dan berpikir bahwa yang akan bertanggung jawab untuk presentasi di depan kelas hanya ketua kelompok saja. Kondisi seperti ini sering terjadi pada mahasiswa yang tidak mendapat tugas sebagai ketua dalam sebuah kelompok diskusi.

Hal tersebut juga menunjukkan bahwa dalam penggunaan metode diskusi, mahasiswa kurang memiliki tanggung jawab untuk belajar mendalami atau mencari tahu materi yang diberikan. Hal ini tentunya berdampak pada rendahnya pemahaman mereka terhadap materi trigonometri yang diajarkan. Hal yang dapat dilakukan untuk meningkatkan tanggung jawab mahasiswa ketika diskusi adalah mengembangkan metode diskusi menjadi metode diskusi bermuatan presentasi sistem rotasi.

Dalam Sugono, dkk. (2008), presentasi diartikan sebagai pemberian, pengucapan pidato, perkenalan, penyajian atau pertunjukan kepada orang-orang yang diundang. Menurut (Prasetiyo \& Mitasari, 2016) bahwa presentasi adalah metode pengungkapan ide, gagasan, perasaan di depan umum oleh satu atau lebih presenter dengan menyertakan naskah makalah atau tidak. Selanjutnya, rotasi diartikan sebagai perputaran (Sugono, dkk., 2008). Perpu-taran dalam arti yang luas merupakan gerakan berputar yang dilakukan oleh satu atau kelompok benda (objek) yang mengelilingi satu benda (objek) lain pada titik tertentu. Dalam hal ini, perputaran diartikan sebagai melakukan sesuatu pekerjaaan secara bergantian oleh individu atau kelompok.

Dalam hal ini, metode diskusi bermuatan presentasi sistem rotasi diartikan sebagai sebuah metode diskusi dengan melibatkan seorang mahasiswa atau kelompok mahasiswa sebagai pemberi materi kepada mahasiswa atau kelompok mahasiswa lain yang dilakukan secara berputar (bergantian) dalam satu kali proses pembelajaran.

Penerapan metode diskusi bermuatan presentasi sistem rotasi ini dilakukan dengan cara, yakni dosen memberikan petunjuk terkait proses pembelajaran yang akan dilakukan, kemudian mahasiswa membentuk kelompok diskusi, kemudian setiap anggota kelompok diskusi secara bergantian memberikan presentasi 
materi kepada anggota lain dalam satu kelompoknya, kemudian setiap kelompok secara bergantian melakukan presentasi materi kepada kelompok lain, kemudian pada bagian akhir menginformasikan hasil penilaian proses yang diperoleh mahasiswa selama pembelajaran.

Melalui metode diskusi bermuatan presentasi sistem rotasi ini, setiap mahasiswa akan dituntut untuk bertanggung jawab menguasai masalah atau materi yang diberikan karena setiap mahasiswa dituntut untuk bisa mempresentasikan materi kepada teman satu kelompok maupun teman di luar kelompoknya. Melalui penerapan metode ini, setiap mahasiswa akan didorong untuk belajar secara aktif mencari tahu tentang materi atau masalah yang diberikan pada setiap proses pembelajaran, sehingga akhirnya dapat meningkatkan prestasi belajar matematika mereka.

\section{Rumusan Masalah}

Rumusan masalah pada penelitian ini adalah apakah metode diskusi bermuatan presentasi sistem rotasi layak (valid, praktis, dan efektif) digunakan dalam pengajaran mata kuliah trigonometri?

\section{Tujuan Penelitian}

Penelitian ini bertujuan untuk menghasilkan metode diskusi bermuatan presentasi sistem rotasi yang layak (valid, praktis, dan efektif) digunakan dalam pengajaran mata kuliah trigonometri.

\section{Manfaat Penelitian}

Hasil pengembangan metode diskusi bermuatan presentasi sistem rotasi ini dapat dijadikan sebagai salah satu alternatif metode pembelajaran yang dapat digunakan oleh para dosen dalam pengajaran mata kuliah trigonometri.

\section{METODE PENELITIAN \\ Desain Penelitian}

Penelitian ini merupakan jenis penelitian dan pengembangan. Menurut Sugiyono dalam Muna, Nazaruddin, \& Murtianto (2017) bahwa penelitian dan pengembangan adalah metode penelitian yang digunakan untuk menghasilkan produk tertentu, dan menguji keefektifan produk tersebut. Uji coba penggunaan metode diskusi bermuatan presentasi sistem rotasi ini dilakukan kepada mahasiswa Program Studi Pendidikan Matematika FKIP Universitas Katolik Santu Paulus Ruteng angkatan tahun 2018.

Instrumen yang digunakan dalam penelitian ini adalah tes, angket, dan wawancara. Tes digunakan untuk mengetahui tingkat efektifitas dari metode diskusi bermuatan presentasi sistem rotasi. Tes diberikan kepada mahasiswa setelah mereka mengikuti pembelajaran trigonometri yang menggunakan metode diskusi bermuatan presentasi sistem rotasi.

Angket digunakan untuk mengetahui tingkat kevalidan dan kepraktisan dari metode diskusi bermuatan presentasi sistem rotasi. Penilaian angket dilakukan berdasarkan skala penilaian Likert. Angket kevalidan diberikan kepada dua orang ahli pada bidang 
pendidikan matematika berdasarkan kepakaran mereka, sedangkan angket kepraktisan diberikan kepada mahasiswa untuk menilai kepraktisan berdasarkan pengalaman yang mereka alami selama mengikuti kuliah trigonometri yang menggunakan metode diskusi bermuatan presentasi sistem rotasi.

Wawancara digunakan untuk mendapatkan data terkait gambaran awal tentang masalah yang dihadapi atau dialami oleh mahasiswa dalam mengikuti perkuliahan trigonometri. Wawancara dilakukan secara tidak terstruktur sebelum diterapakannya metode diskusi bermuatan presentasi sistem rotasi.

Langkah pengembangan pada penelitian ini dilakukan dengan memodifikasi model pengembangan 4D dari Thiagarajan, Semmel \& Semmel (1974) yakni tahap pendefinisian (define), tahap perancangan (design), tahap pengembangan (develop), dan tahap penyebaran (disseminate).

\section{Tahap Pendefinisian (Define)}

Pada tahap ini, peneliti melakukan analisis terkait kebututuhan dalam pelaksanaan proses perkuliahan, khususnya pada pengajaran mata kuliah trigonometri.

\section{Tahap Perancangan (Design)}

Pada tahap ini, peneliti merancang pengembangan langkah-langkah metode diskusi bermuatan presentasi sistem rotasi.

\section{Tahap Pengembangan (Develop)}

Pada tahap ini, peneliti melakukan uji validitas, uji kepraktisan, dan uji keefektifan sehingga dapat menghasilkan metode diskusi bermuatan presentasi sistem rotasi yang layak (valid, praktis, dan efektif).

\section{Uji Validitas}

Pengujian validitas metode diskusi bermuatan presentasi sistem rotasi diperoleh dari data angket kevalidan yang telah dinilai oleh dua orang ahli pada bidang pendidikan matematika. Langkah-langkah yang dilakukan untuk menguji validitas adalah sebagai berikut. Skor angket dari masing-masing ahli dijumlahkan, kemudian total skor yang diperoleh dari dua orang ahli kemudian dikonversi kedalam data kualitatif berdasarkan kriteria kevalidan pada Tabel 1.

Tabel 1. Kriteria Kevalidan

\begin{tabular}{|c|c|c|}
\hline Nilai Kevalidan & Kategori & Keterangan \\
\hline $85,1 \%-100 \%$ & $\begin{array}{l}\text { Sangat } \\
\text { Valid }\end{array}$ & $\begin{array}{l}\text { Dapat } \\
\text { digunakan } \\
\text { tanpa revisi }\end{array}$ \\
\hline $70,1 \%-85 \%$ & $\begin{array}{l}\text { Cukup } \\
\text { Valid }\end{array}$ & $\begin{array}{l}\text { Dapat } \\
\text { digunakan } \\
\text { tetapi } \\
\text { dilakukan } \\
\text { revisi kecil }\end{array}$ \\
\hline $50,1 \%-70 \%$ & $\begin{array}{c}\text { Kurang } \\
\text { Valid }\end{array}$ & $\begin{array}{l}\text { Disarankan } \\
\text { untuk tidak } \\
\text { dipergunakan } \\
\text { karena perlu } \\
\text { revisi besar }\end{array}$ \\
\hline $0,1 \%-50 \%$ & $\begin{array}{l}\text { Tidak } \\
\text { Valid }\end{array}$ & $\begin{array}{l}\text { Tidak boleh } \\
\text { digunakan }\end{array}$ \\
\hline
\end{tabular}

Nilai kevalidan diperoleh dari skor angket yang diberikan oleh ahli 1 dan ahli 2, dengan menggunakan perhitungan sebagai berikut.

$$
N v=\frac{S a 1+S a 2}{S M a 1+S M a 2} \times 100 \%
$$


Keterangan:

$\mathrm{Nv}$ : Nilai Kevalidan

Sa : Skor Ahli

SMa : Skor Maksimal Ahli

\section{Uji Kepraktisan}

Pengujian kepraktisan metode diskusi bermuatan presentasi sistem rotasi diperoleh dari data angket kepraktisan yang dinilai oleh mahasiswa. Mahasiwa memberikan penilaian berdasarkan pengalaman mereka selama mengikuti mata kuliah trigonometri dengan menggunakan metode diskusi bermuatan presentasi sistem rotasi. Analisis tingkat kepraktisan dapat dihitung dengan menggunakan rumus sebagai berikut.

$$
N p=\frac{T S E p}{S . M a x} \times 100 \%
$$

Keterangan:

Np : Nilai kepraktisan

TSEp : Total skor empirik kepraktisan

S.Max : Skor maksimum yang diharapkan

Setelah mengetahui nilai kepraktisan, maka selanjutnya mendeskripsikan hasil kepraktisan dengan mengacu pada kriteria pada Tabel 2.

Tabel 2. Kriteria Kepraktisan

\begin{tabular}{|c|c|c|}
\hline Kriteria & Kategori & Keterangan \\
\hline $75,01 \%-100 \%$ & $\begin{array}{l}\text { Sangat } \\
\text { Praktis }\end{array}$ & $\begin{array}{l}\text { Dapat } \\
\text { digunakan } \\
\text { tanpa revisi }\end{array}$ \\
\hline $50,01 \%-75,00 \%$ & Praktis & $\begin{array}{l}\text { Dapat } \\
\text { digunakan } \\
\text { tetapi } \\
\text { dilakukan } \\
\text { revisi sedikit }\end{array}$ \\
\hline $25,01 \%-50,00 \%$ & $\begin{array}{l}\text { Kurang } \\
\text { Praktis }\end{array}$ & $\begin{array}{l}\text { Disarankan } \\
\text { untuk tidak } \\
\text { dipergunakan }\end{array}$ \\
\hline $00,00 \%-25,00 \%$ & $\begin{array}{l}\text { Tidak } \\
\text { Praktis }\end{array}$ & $\begin{array}{l}\text { Tidak dapat } \\
\text { digunakan }\end{array}$ \\
\hline
\end{tabular}

\section{Uji Keefektifan}

Kefektifan metode diskusi bermuatan presentasi sistem rotasi ini diukur dari hasil tes belajar mahasiswa setelah mengikuti mata kuliah trigonometri dengan menggunakan metode diskusi bermuatan presentasi sistem rotasi. Kriteria keefektifan ketuntasan belajar mahasiswa secara klasikal terangkum dalam Tabel 3.

Tabel 3. Kriteria Keefektifan

\begin{tabular}{cc}
\hline $\begin{array}{c}\text { Interval Presentasi } \\
\text { Ketuntasan }\end{array}$ & Kriteria \\
\hline $81 \%-100 \%$ & Sangat Efektif \\
$61 \%-80 \%$ & Efektif \\
$41 \%-60 \%$ & Kurang Efektif \\
$21 \%-40 \%$ & Tidak Efektif \\
$0 \%-20 \%$ & Sangat Tidak Efektif \\
\hline & (Sumber: Ningsih, 2019)
\end{tabular}

Nilai ketuntasan (Nk) diperoleh dari perhitungan sebagai berikut.

$$
\mathrm{Nk}=\frac{\text { Nilai Rata-Rata Empiris }}{\text { Nilai Maksimal }} \times 100 \%
$$

\section{Tahap Penyebaran (Disseminate)}

Pada tahap ini, jika metode diskusi bermuatan presentasi sistem rotasi yang telah dikembangkan dinyatakan layak (valid, praktis, dan efektif) maka selanjutnya akan diberikan kepada kelas yang lebih luas pada pengajaran mata kuliah trigonometri.

Secara garis besar, alur penelitian ini ditunjukkan pada Gambar 1.

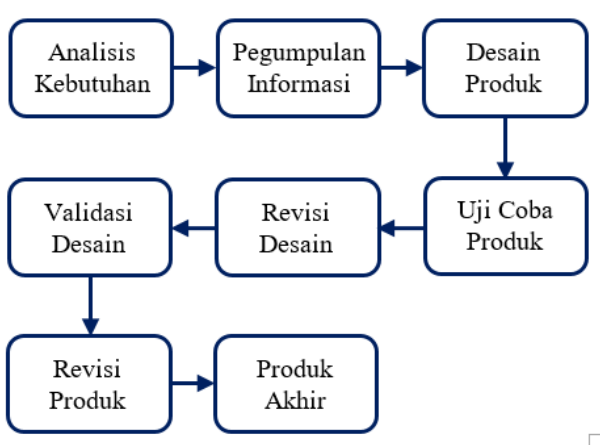

Gambar 1. Bagan Alur Penelitian 


\section{HASIL DAN PEMBAHASAN}

Hasil penelitian ini berorientasi pada pengembangan metode pembelajaran sebagai produk akhir. Produk akhir yang dihasilkan adalah metode diskusi bermuatan presentasi sistem rotasi yang layak (valid, praktis, dan efektif). Berdasarkan penelitian yang telah dilakukan, maka diperoleh hasil sebagai berikut.

\section{Tahap Pendefinisian (Define)}

Pada tahap ini diperoleh data bahwa proses pembelajaran pada mata kuliah trigonometri yang sebelumnya menggunakan metode presentasi kelompok tidak meningkatkan partisipasi aktif dari setiap mahasiswa. Mahasiswa yang paling dominan aktif hanya mahasiswa dan kelompok mahasiswa yang bertugas untuk presentasi materi di depan kelas sedangkan mahasiwa yang tidak mendapat tugas presentasi cendrung pasif.

Selain itu, hasil wawancara tidak terstruktur yang dilakukan oleh peneliti dengan beberapa mahasiswa angkatan tahun 2018 Prodi Pendidikan Matematika FKIP Universitas Katolik Indonesia Santu Paulus Ruteng diperoleh data bahwa, ketika mahasiwa tidak mendapat tugas untuk presentasi maka mereka cendrung tidak akan belajar materi secara sungguh sebelum mengikuti kuliah karena mereka beranggapan bahwa yang memiliki tanggung jawab penuh pada saat pembelajaran adalah mahasiswa dan kelompok mahasiswa yang bertugas presentasi materi. Hal inilah yang menjadi salah satu penyebab sehingga mahasiwa tidak mendapatkan hasil belajar matematika yang maksimal pada waktu-waktu sebelumnya. Berdasarkan hasil analisis awal ini, peneliti telah memiliki gambaran terkait penyempurnaan desain metode diskusi bermuatan presentasi sistem rotasi yang dikembangkan.

\section{Tahap Perancangan (Design)}

Pada tahap ini, peneliti merancang pengembangan langkah-langkah metode diskusi bermuatan presentasi sistem rotasi, yakni sebagai berikut.

\section{Tahap Pembagian Kelompok}

- Dosen membagi mahasiswa kedalam beberapa kelompok diskusi yang anggotanya heterogen (4 - 5 orang).

- Dosen menyajikan materi atau masalah matematis untuk dipecahkan oleh masing-masing kelompok.

\section{Tahap Presentasi Rotasi Dalam Kelompok}

- Mahasiswa melakukan diskusi dalam kelompoknya masing-masing.

- Setiap mahasiswa secara bergantian untuk presentasi materi atau masalah dalam internal kelompoknya.

- Setiap kelompok menyimpulkan hasil diskusi kelompoknya.

- Masing-masing mahasiswa dalam setiap kelompok, mencatat hasil diskusi kelompok secara sistematis.

\section{Tahap Presentasi Rotasi Luar Kelompok}

- Menentukan satu kelompok sebagai koordinator diskusi antar kelompok, dan memandu jalanya diskusi di depan kelas.

- Kelompok koordinator diskusi memberikan kesempatan kepada kelompok lain untuk mempresentasi- 
kan hasil diskusi kelompok mereka dari tempat duduknya masingmasing.

- Kelompok yang mendapat giliran presentasi harus melibatkan semua anggota kelompoknya untuk memberikan presentasi secara bergantian.

- Jika tangangapan (presentasi) dari masing-masing kelompok sudah dilakukan, maka kelompok koordinator diskusi bertugas untuk menyimpulkan hasil diskusi antar kelompok.

\section{Tahap Penyampaian Hasil Penilaian Proses}

- Dosen menginformasikan hasil penilaian yang telah dilakukan selam proses pembelajran yang telah berlangsung.

\section{Tahap Pengembangan (Develop)}

Pada tahap ini, peneliti terlebih dahulu berkonsultasi kepada 2 orang ahli pada bidang pendidikan matematika untuk melihat aspek kelogisan dan kemudahan dari langkah-langkah metode diskusi bermuatan presentasi sistem rotasi jika diterapkan dalam pengajaran mata kuliah trigonometri. Rangkuman catatan dari 2 orang ahli tersebut adalah sebagai berikut. (1) Perlu diperbaiki tata tulis pada beberapa langkah metode diskusi bermuatan presentasi sistem rotasi; (2) mempertimbangkan kebutuhan waktu untuk presentasi; (3) memperjelas apa yang akan didiskusikan oleh mahasiswa; dan (4) memperjelas kondisi mahasiswa pada saat diskusi dalam kelompok maupun diskusi luar kelompok.
Berdasarkan cacatan dari para ahli tersebut, maka dilakukan revisi langkahlangkah metode diskusi bermuatan presentasi sistem rotasi yang disajikan pada Tabel 4.

\section{Hasil Uji Validitas}

Hasil uji kevalidan metode diskusi bermuatan presentasi sistem rotasi diperoleh dari penilaian angket kevalidan oleh 2 orang ahli pada bidang pendidikan matematika. Hasil kevalidan ini diperoleh melalui langkah-langkah sebagai berikut. (1) Menghitung skor total rata-rata kevalidan, (2) mengkonversi skor total rata-rata kevalidan kedalam nilai kevalidan, (3) mengkonversi nilai kevalidan kedalam kriteria tingkat kevalidan.

Tabel 5. Skor Total Rata-Rata Kevalidan

\begin{tabular}{lc}
\hline \multicolumn{1}{c}{ Aspek Yang Divalidasi } & Rata-Rata \\
\hline $\begin{array}{l}\text { Relevansi dengan pengajaran materi } \\
\text { trigonometri. }\end{array}$ & 5 \\
$\begin{array}{l}\text { Relevansi dengan level kognitif } \\
\text { mahasiswa. }\end{array}$ & 4,5 \\
$\begin{array}{l}\text { Mempermudah/memperlancar } \\
\text { mahasiswa untuk menyampaikan }\end{array}$ & 5 \\
$\quad \begin{array}{l}\text { ide matematika pada saat } \\
\text { pembelajaran. }\end{array}$ & \\
$\begin{array}{l}\text { Mendorong mahasiswa untuk aktif } \\
\text { pada saat pembelajaran. }\end{array}$ & 4 \\
$\begin{array}{l}\text { Mahasiswa memiliki kesempatan } \\
\text { yang luas untuk menyampaikan } \\
\text { ide matematika. }\end{array}$ & 5 \\
$\begin{array}{l}\text { Mempermudah mahasiswa untuk } \\
\text { memahami materi trigonometri. } \\
\text { Mendorong mahasiswa untuk kreatif } \\
\text { pada saat pembelajaran. }\end{array}$ & 5 \\
$\begin{array}{l}\text { Mendorong mahasiswa untuk } \\
\text { membangun pengetahuan sendiri } \\
\text { pada saat pembelajaran. }\end{array}$ & 5,5 \\
$\begin{array}{l}\text { Mendorong mahasiswa untuk } \\
\text { interaktif pada saat pembelajaran. }\end{array}$ & 5,5 \\
\hline \begin{tabular}{l} 
Skor Total Rata-Rata Kevalidan \\
\hline
\end{tabular} & 52,5 \\
\hline
\end{tabular}


Tabel 4. Hasil Pengembangan Langkah-Langkah Metode Diskusi Bermuatan Presentasi Sistem Rotasi

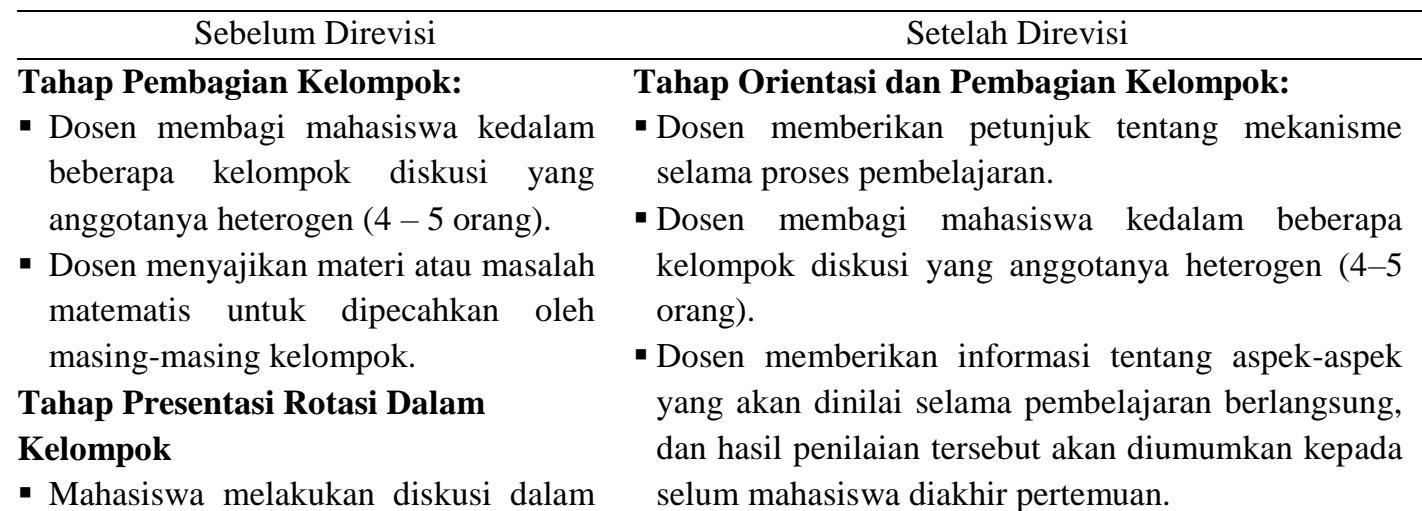
kelompoknya masing-masing.

\section{Tahap Penyajian Masalah:}

- Setiap mahasiswa secara bergantian untuk presentasi materi atau masalah dalam internal kelompoknya.

- Setiap kelompok menyimpulkan hasil diskusi kelompoknya.

- Masing-masing mahasiswa dalam setiap kelompok, mencatat hasil diskusi kelompok secara sistematis.

Tahap Presentasi Rotasi Luar

Kelompok

- Menentukan satu kelompok sebagai koordinator diskusi antar kelompok, dan memandu jalanya diskusi di depan kelas.

- Dosen menyajikan materi atau masalah matematis yang berkaitan dengan trigonometri untuk dipecahkan oleh masing-masing kelompok.

Tahap Presentasi Rotasi Dalam Kelompok:

- Mahasiswa melakukan diskusi dalam kelompoknya masing-masing.

- Setiap mahasiswa secara bergantian untuk mempresentasikan pemecahan masalah yang telah diberikan oleh dosen dalam internal kelompoknya.

- Setiap kelompok menyimpulkan hasil diskusi kelompoknya.

- Masing-masing mahasiswa dalam setiap kelompok, mencatat hasil diskusi kelompok secara sistematis.

- Kelompok koordinator diskusi memberikan kesempatan kepada kelompok lain untuk mempresentasikan hasil diskusi kelompok mereka dari tempat duduknya masing-masing.

Tahap Presentasi Rotasi Luar Kelompok:

- Kelompok yang mendapat giliran presentasi harus melibatkan semua anggota kelompoknya untuk memberikan presentasi secara bergantian.

- Dosen mengundi secara acak untuk menentukan kelompok yang bertugas sebagai kelompok koordinator diskusi.

- Menentukan satu kelompok sebagai koordinator diskusi antar kelompok, dan memandu jalanya diskusi di depan kelas.

- Kelompok koordinator diskusi memberikan kesempatan kepada kelompok lain untuk mempresentasikan hasil diskusi kelompok mereka dari tempat duduknya masing-masing.

- Kelompok yang mendapat giliran presentasi harus

- Jika tangangapan (presentasi) dari masing-masing kelompok sudah dilakukan, maka kelompok koordinator diskusi bertugas untuk menyimpulkan hasil diskusi antar kelompok.

Tahap Penyampaian Hasil Penilaian

Proses melibatkan semua anggota kelompoknya untuk memberikan presentasi secara bergantian.

- Jika tangangapan (presentasi) dari masing-masing kelompok sudah dilakukan, maka kelompok koordinator diskusi bertugas untuk menyimpulkan hasil diskusi antar kelompok.

Tahap Penyampaian Hasil Penilaian Proses:

- Dosen menginformasikan hasil penilaian yang telah dilakukan selam proses pembelajran yang telah berlangsung.

- Dosen menginformasikan hasil penilaian yang telah dilakukan selam proses pembelajran yang telah berlangsung. 
Setelah mendapatkan skor total rata-rata kevalidan, maka selanjutnya dikonversi ke nilai kevalidan (Nv), yakni sebagai berikut.

$$
\mathrm{Nv}=\frac{42,5}{45} \times 100 \%=94,44 \%
$$

Berdasarkan kriteria kevalidan, maka ditunjukkan tingkat kevalidan metode diskusi bermuatan presentasi sistem rotasi sebagai berikut.

Tabel 6. Kriteria Kevalidan

\begin{tabular}{ccc}
\hline Nilai Kevalidan & Kategori & Keterangan \\
\hline $94,444 \%$ & $\begin{array}{c}\text { Sangat } \\
\text { Valid }\end{array}$ & $\begin{array}{c}\text { Dapat } \\
\text { digunakan } \\
\text { tanpa revisi }\end{array}$ \\
\hline
\end{tabular}

Berdasarkan kriteria kevalidan tersebut, maka disimpulkan bahwa metode diskusi bermuatan presentasi sistem rotasi masuk kategori "Sangat Valid". Hal tersebut berarti bahwa metode diskusi bermuatan presentasi sistem rotasi sanggat valid diterapkan dalam pengajaran mata kuliah trigonometri sehingga dapat digunakan tanpa revisi.

Berdasarkan aspek-aspek kevalidan yang telah dinilai oleh 2 orang ahli pada bidang pendidkan matematika tersebut, maka secara spesifik dapat dijelaskan sebagai berikut. (1) Metode diskusi bermuatan presentasi sistem rotasi memiliki relevansi dengan pengajaran materi trigonometri dan kognitif mahasiswa, (2) metode diskusi bermuatan presentasi sistem rotasi dapat mempermudah atau memperlancar mahasiswa untuk menyampaikan ide matematika pada saat pembelajaran, (3) metode diskusi bermuatan presentasi sistem rotasi ahli menilai dapat mendorong mahasiswa untuk aktif pada saat pembelajaran, (4) metode diskusi bermuatan presentasi sisitem rotasi dapat memberikan kesempatan yang luas kepada mahasiswa untuk menyampaikan ide matematika, (5) metode diskusi bermuatan presentasi sisitem rotasi dapat mempermudah mahasiswa untuk memahami materi trigonometri, (6) metode diskusi bermuatan presentasi sisitem rotasi dapat mendorong mahasiswa untuk kreatif pada saat pembelajaran, (7) metode diskusi bermuatan presentasi sisitem rotasi dapat mendorong mahasiswa untuk membangun pengetahuan sendiri pada saat pembelajaran, (8) metode diskusi bermuatan presentasi sisitem rotasi dapat mendorong mahasiswa untuk interaktif pada saat pembelajaran.

\section{Hasil Uji Kepraktisan}

Hasil uji tingkat kepraktisan metode diskusi bermuatan presentasi sistem rotasi diperoleh dari penilaian angket kepraktisan oleh mahasiswa. Hasil tingkat kepraktisan ini diperoleh melalui langkah-langkah sebagai berikut: (1) menghitung skor total ratarata kepraktisan, (2) mengkonversi skor total rata-rata kepraktisan kedalam nilai kepraktisan, (3) mengkonversi nilai kepraktisan kedalam kriteria tingkat kepraktisan.

Setelah mendapatkan skor total rata-rata kepraktisan, maka selanjutnya dikonversi ke nilai kepraktisan sebagai berikut.

$$
\begin{aligned}
N p & =\frac{T S E p}{S . M a x} \times 100 \%=\frac{34,35}{40} \times 100 \% \\
& =85,875 \%
\end{aligned}
$$


Tabel 7. Skor Total Rata-Rata Kepraktisan

\begin{tabular}{|c|c|}
\hline Aspek Kepraktisan & $\begin{array}{l}\text { Skor } \\
\text { Rata- } \\
\text { Rata }\end{array}$ \\
\hline $\begin{array}{l}\text { Mempermudah mahasiswa untuk } \\
\text { saling berinteraksi pada saat } \\
\text { pembelajaran. }\end{array}$ & 4,2 \\
\hline $\begin{array}{l}\text { Mempermudah/memperlancar } \\
\text { mahasiswa untuk menyampaikan } \\
\text { ide matematika pada saat } \\
\text { pembelajaran. }\end{array}$ & 4,35 \\
\hline $\begin{array}{l}\text { Mendorong mahasiswa untuk aktif } \\
\text { pada saat pembelajaran. }\end{array}$ & 4,3 \\
\hline $\begin{array}{l}\text { Mahasiswa memiliki kesempatan } \\
\text { yang luas untuk menyampaikan } \\
\text { ide matematika. }\end{array}$ & 4,15 \\
\hline $\begin{array}{l}\text { Mempermudah mahasiswa untuk } \\
\text { memahami materi trigonometri. }\end{array}$ & 4,4 \\
\hline $\begin{array}{l}\text { Mendorong mahasiswa untuk } \\
\text { kreatif pada saat pembelajaran. }\end{array}$ & 4,4 \\
\hline $\begin{array}{l}\text { Mendorong mahasiswa untuk } \\
\text { membangun pengetahuan sendiri } \\
\text { pada saat pembelajaran. }\end{array}$ & 4,45 \\
\hline $\begin{array}{l}\text { Relevan dengan level kognitif } \\
\text { mahasiswa. }\end{array}$ & 4,1 \\
\hline Skor Total Rata-Rata Kepraktisan & 34,35 \\
\hline
\end{tabular}

Berdasarkan kriteria nilai kepraktisan, maka ditunjukkan tingkat kepraktisan metode diskusi bermuatan presentasi sistem rotasi pada Tabel 8 berikut.

Tabel 8. Nilai Tingkat Kepraktisan

\begin{tabular}{ccc}
\hline $\begin{array}{c}\text { Nilai } \\
\text { Kepraktisan }\end{array}$ & Kategori & Keterangan \\
\hline $85,875 \%$ & $\begin{array}{c}\text { Sangat } \\
\text { Praktis }\end{array}$ & $\begin{array}{c}\text { Dapat } \\
\text { digunakan } \\
\text { tanpa revisi }\end{array}$
\end{tabular}

Berdasarkan nilai tingkat kepraktisan tersebut, maka disimpulkan bahwa metode diskusi bermuatan presentasi sistem rotasi masuk kategori "Sangat Praktis". Hal tersebut berarti bahwa metode diskusi bermuatan presentasi sistem rotasi sanggat praktis diterapkan dalam pengajaran mata kuliah trigonometri sehingga dapat digunakan tanpa revisi.

Berdasarkan aspek-aspek kepraktisan yang telah dinilai oleh mahasiswa, maka secara spesifik dapat dijelaskan sebagai berikut. (1) Metode diskusi bermuatan presentasi sistem rotasi dapat mempermudah mahasiswa untuk saling berinteraksi pada saat pembelajaran, (2) metode diskusi bermuatan presentasi sistem rotasi dapat mempermudah atau memperlancar mahasiswa untuk menyampaikan ide matematika pada saat pembelajaran, (3) metode diskusi bermuatan presentasi sistem rotasi dapat mendorong mahasiswa untuk aktif pada saat pembelajaran, (4) metode diskusi bermuatan presentasi sistem rotasi dapat memberikan kesempatan yang luas kepada mahasiswa untuk menyampaikan ide matematika, (5) metode diskusi bermuatan presentasi sistem rotasi dapat mempermudah mahasiswa untuk memahami materi trigonometri, (6) metode diskusi bermuatan presentasi sistem rotasi dapat mendorong mahasiswa untuk kreatif pada saat pembelajaran, (7) metode diskusi bermuatan presentasi sistem rotasi dapat mendorong mahasiswa untuk membangun pengetahuan mereka sendiri pada saat pembelajaran, (8) metode diskusi bermuatan presentasi sistem rotasi relevan dengan level kognitif mahasiswa.

\section{Hasil Uji Keefektifan}

Setelah mengikuti perkuliahan trigonometri, mahasiswa diberikan tes untuk mengukur sejauh mana tingakat 
efektifitas dari metode diskusi bermuatan presentasi sistem rotasi yang sudah dikembangkan. Setelah mahasiswa diberikan tes, diperoleh nilai ratarata sama dengan 82,4 dan jika dikonversi kedalam persentase kriteria keefektifan maka nilai rata-rata tersebut masuk dalam kategori "Sangat Efektif". Hal tersebut menunjukkan bahwa metode diskusi bermuatan presentasi sistem rotasi yang sudah dikembangkan efektif ketika diterapkan pada pengajaran mata kuliah trigonometri.

\section{Tahap Penyebaran (Disseminate)}

Oleh karena metode diskusi bermuatan presentasi sistem rotasi yang telah dikembangkan dinyatakan valid, praktis, dan efektif maka selanjutnya peneliti menerapkan metode diskusi bermuatan presentasi sistem rotasi ini kepada kelas lain untuk digunakan pada pengajaran mata kuliah trigonometri. Produk akhir dari penelitian pengembangan ini adalah metode diskusi bermuatan presentasi sistem rotasi.

\section{PENUTUP}

\section{Kesimpulan}

Metode diskusi bermuatan presentasi sistem rotasi yang telah dikembangkan ini dinyatakan telah memenuhi syarat valid, praktis, dan efektif. Oleh karena itu, maka metode diskusi bermuatan presentasi sistem rotasi dapat digunakan secara luas pada pengajaran mata kuliah trigonometri.

\section{Saran}

Penerapan metode diskusi bermuatan presentasi sistem rotasi ini hanya terbatas pada pengajaran mata kuliah trigonometri. Oleh karena itu, peneliti menyarankan agar metode diskusi bermuatan presentasi sistem rotasi ini dapat dikembangkan dengan menerapkannya pada pengajaran mata kuliah lain, khususnya mata kuliah pada bidang keilmuan matematika.

\section{DAFTAR PUSTAKA}

Akbar, S. (2011). Pengembangan Kurikulum dan Pembelajaran Ilmu Pegetahuan Sosial. Yogyakarta: Cipta Media.

Akbar S. (2013). Instrument perangkat pembelajaran. Bandung: PT Remaja Rosdakarya.

Lutvaidah, U. (2015) Pengaruh Metode dan Pendekatan Pembelajaran Terhadap Penguasaan Konsep Matematika. Jurnal Formatif, 5(3), 279-285.

Majid, A. (2013). Strategi Pembelajaran. Bandung: Remaja Rosdakarya.

Muna, H., Nazaruddin \& Murtianto, Y.H. (2017). Pengembangan Video Pembelajaran Matematika Berbantuan Macromedia Flash 8 dengan Pendekatan Kontekstual Pada Materi Program Linier Kelas XI. Jurnal Aksioma, 8 (2), 9-18.

Ningsih, S.C. (2019). Pengembangan Student Worksheet Berbahasa Inggris dengan Pendekatan Problem Based Learning pada Mata Kuliah Matematika Diskrit. Journal of Medives: Journal of Mathematics Education IKIP Veteran Semarang, 3 (1), 65-74.

Prasetiyo, N.A. \& Mitasari, Z. (2016). Penerapan Metode Diskusi-Presentasi Dipadu Analisis Kritis Artikel 
melalui Lesson Study untuk Meningkatkan Pemahaman Konsep, Kemampuan Berpikir Kritis, dan Komunikasi. Jurnal Bioedukatika, 4 (1), 11-14.

Sugono, D., dkk. (2008). Kamus Bahasa Indonesia. Jakarta: Pusat Bahasa Departemen Pendidikan Nasional.
Suryosubroto, B. (2009). Proses Belajar Mengajar di Sekolah. Jakarta: PT Rineka Cipta.

Thiagarajan, S., Semmel, D., \& Semmel, M. (1974). Instructional development for training teachers and exceptional children a sourcebook. Indianapolis: Indiana University. 